\title{
First description of French V. tubiashii strains pathogenic to mollusk: II. Characterization of properties of the proteolytic fraction of extracellular products
}

\author{
Rachida Mersni Achour ${ }^{a, b, f}$, Nathalie Imbert $^{c}$, Valérie Huet ${ }^{\mathrm{d}}$, Yosra Ben Cheikh ${ }^{\mathrm{a}}$, Nicole Faury, \\ Ibtissem Doghri $^{a}$, Sonia Rouatbi ${ }^{c}$, Stéphanie Bordenave ${ }^{a}$, Marie-Agnès Travers ${ }^{b}$, Denis Saulnier ${ }^{b, e}$, \\ Ingrid Fruitier-Arnaudin ${ }^{a, f,}$
}

a UMR 7266 CNRS-ULR, LIENSs, Equipe Approches Moléculaires, Environnement-Santé, Université de La Rochelle, Avenue Michel Crépeau, 17042 La Rochelle, France

${ }^{\mathrm{b}}$ Ifremer, SG2M-LGPMM, Laboratoire de Génétique et Pathologie des Mollusques Marins, Avenue de Mus de Loup, 17390 La Tremblade, France

c UMR 7266 CNRS-ULR, LIENSs, Equipe Animaux MARins à la variabilité Environnementale, Université de La Rochelle, Avenue Michel Crépeau, 17042 La Rochelle, France

d LIENSs, UMR 6250, CNRS-Université de La Rochelle, 2 rue Olympe de Gouges, F-17042 La Rochelle Cedex 01, France

e Ifremer, Centre Ifremer du Pacifique, UMR 241 Ecosystèmes Insulaires Océaniens, Tahiti, 98719 Taravao, French Polynesia

${ }^{f}$ Fédération de Recherche en Environnement et Développement Durable, FR CNRS 3097, Université de La Rochelle, France

\footnotetext{
*: Corresponding author : Rachida Mersni Achour, fax: + 33546458265 ; email address : ingrid.fruitier@univ-Ir.fr
}

\section{Abstract:}

Extracellular products (ECPs) of the French Vibrio tubiashii strain 07/118 T2 were previously reported to be toxic for the Pacific oyster Crassostrea gigas. In this study we now assessed host cellular immune responses and bacterial potential effectors by which these ECPs can be associated with host damages.

The adhesion capacity (28\% inhibition) and phagocytosis ability (56\% inhibition) of oyster hemocytes were the main functions affected following in vitro contact between hemocytes and V. tubiashii ECPs. This may be linked to the demonstration of the capability of ECPs to cleave various cellular substrates as oyster collagen.

Moreover, a strong metalloproteolytic activity was recorded with general (azocasein) and specific (ADAM) substrates and characterized by the use of standard inhibitors and metal ions. The addition of 1,10-phenanthroline and $\mathrm{Zn}^{2+}$ decreased proteolytic activity by about $80 \%$ and $50 \%$ respectively, confirming the presence of zinc metalloproteolytic activity in the ECPs. Mass spectrometry analyses of crude ECPs identified an extracellular zinc metalloprotease encoded by a gene with an open reading frame of $1821 \mathrm{bp}$ (606 aa). Consensus zinc-binding motifs specific to thermolysin family and some glycosylation and phosphorylation sites were located on the deduced protein sequence. 
Taken together, our results suggest that this (these) zinc metalloprotease(s) might contribute to the impairment of hemocyte immunological functions; however, their direct involvement in ECPs toxicity remains to be demonstrated.

\section{Graphical abstract}

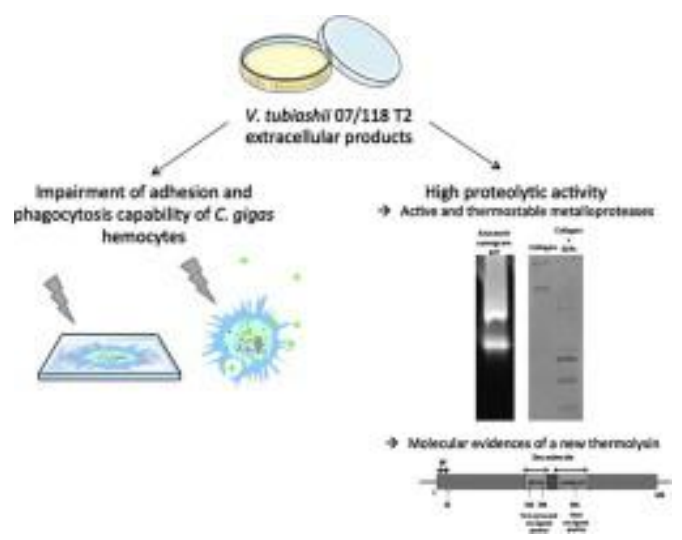

\section{Highlights}

Crude ECPs of $V$. tubiashii impair immune functions of oyster hemocytes in vitro. Biochemical analyses showed the presence of a zinc metalloprotease. Gene sequencing classify it in the thermolysin family.

Keywords : ECPs ; Oyster immune responses ; Thermolysin-metalloprotease ; Mass spectroscopy ; ADAM substrate ; Vibrio 


\section{Introduction}

Vibriosis is economically the most important bacterial disease affecting several species of marine organisms, at all its life stages, in their natural habitat and especially in aquaculture systems. Among these species, $V$. tubiashii is one of the main causative agents of larval and juvenile bivalve mollusc mortalities in hatcheries. Vibrio tubiashii, originally found in American seas (Elston et al., 2008; Hada et al., 1984; Tubiash et al., 1970, 1965), after in England (Jeffries, 1982), later in Spain (Lodeiros et al., 1987) and recently in France (Travers et al., 2014) is considered as the causative agent of bacillary necrosis affecting early life stages of molluscan bivalves of the hard clam and the oyster. This disease is characterized by a reduction in larval motility and necrosis in extensive soft tissue (Elston et al., 2008; Estes et al., 2004; Tubiash et al., 1965).

Usually, during infection steps, various bacterial adhesion factors are expressed to allow the contact with the host cell that is necessary for the secretion of effectors and toxin proteins (Broberg et al., 2011). Some secreted factors are also involved in bacterial penetration, i.e. host tissue lysis. These secreted toxins factors are often designated as extracellular products (ECPs) and are typically composed of various proteins that possess cytotoxic, cytolytic and immunosupressive activities such as enterotoxins, hemolysins, cytotoxins, lipases, adhesive agents, exopolysaccharide, siderophores and proteases (Shinoda and Miyoshi, 2011; Travis et al., 1995). Various studies on virulent $V$. tubiashii strains have shown that these bacteria secrete extracellular toxins with proteolytic and hemolytic activities (Delston et al., 2003; Kothary et al., 2001).

Bacterial proteases are generally described as one of the most toxic factors to the host, constantly implicated in virulence and pathogenicity (Shinoda et al., 1996). Many toxic proteases are zincdependent metalloproteases (Miyoshi and Shinoda, 2000a).

In a recent study, different bacterial isolates from diseased abalone (Haliotis tuberculata) and oysters (C. gigas) spat in a French experimental hatchery/nursery during mortalities events between 2004 and 2008, was identified as belonging to $V$ tubiashii species. As we had previously demonstrated the virulence of $V$. tubiashii $07 / 118$ T2 and the toxicity of their ECPs on juvenile oysters (Travers et al., 2014), in this study we now assessed host cellular immune responses and bacterial potential effectors by which these ECPs can be associated with host damages. The main objective of this work was to achieve a biochemical and molecular identification of these toxic ECPs coupled with the evaluation of their biological activities by (1) the identification of exoproteolytic fraction using electrophoretic, enzymatic, molecular and mass spectrometry analyses, (2) the determination of the effect of ECPs on the cellular immune response of the oyster.

\section{Materials and methods}

\subsection{Materials}

All reagents, unless otherwise specified, were purchased from Sigma Aldrich ${ }^{\circledR}$ (St Quentin Falavier, France). The ADAM substrate Dabcyl-Leu-Ala-Gln-Ala-Homophe-Arg-Ser-Lys (5FAM)- $\mathrm{NH}_{2}$ was purchased from Enzo life Sciences ${ }^{\circledR}$ (USA) and was more than $95 \%$ pure. Sypro Ruby protein gel stain and molecular weight markers (Precision Plus Protein ${ }^{\mathrm{TM}}$ Unstained Standards) were provided by BIO-RAD. Page Blue Protein Staining Solution and molecular weight markers (Page Ruler Plus Prestained Protein Ladder) were purchased from Thermo Scientific. The cellular probes (Propidium iodide, FluoSpheres red, Fluorescein Diacetate, Fluo-4, 
AM and LysoTracker Green DND-26) were provided by Life Technologies ${ }^{\mathrm{TM}}$, and Molecular Probes $^{\circledR} \cdot$ For PCR, Taq polymerase mixes (Diamond Taq ${ }^{\circledR}$ DNA polymerase) were purchased from Eurogentec and dNTPs (dNTP Master Mix) from Euromedex.

\subsection{Bacterial isolates and culture conditions}

Vibrio tubiashii 07/118 T2, isolated from moribund oysters during mollusk mortalities reported in hatcheries in France in 2007, was used in this study (Travers et al., 2014). Culture of 07/118 T2 was routinely performed in Luria-Bertani medium (Difco) supplemented with $1 \%$ sodium chloride (LBS-1\% NaCl). Stock culture was stored at $-80^{\circ} \mathrm{C}$ in LBS with glycerol $15 \%(\mathrm{v} / \mathrm{v})$.

\subsection{Preparation of extracellular products and estimation of protein concentration and profile}

Extracellular products were produced using the cellophane overlay method as described previously by Travers et al. (Travers et al., 2014). Briefly, bacteria were grown in $5 \mathrm{ml}$ of LBS$1 \% \mathrm{NaCl}$ at $22^{\circ} \mathrm{C}$ for $18 \mathrm{~h}$. A volume of $1 \mathrm{ml}$ of exponential phase culture $\left(\mathrm{OD}_{600}=1\right)$ was spread on a sterile cellophane film overlying LBSA (LBS Agar) plates. After $48 \mathrm{~h}$ of culture at $22^{\circ} \mathrm{C}$, the cells were washed off the cellophane using $10 \mathrm{ml}$ of cold sterile artificial sea water (SASW) and removed by centrifugation at $3,000 \times \mathrm{g}\left(45 \mathrm{~min}\right.$ at $\left.4^{\circ} \mathrm{C}\right)$. The supernatant was filtered at $0.22 \mu \mathrm{m}$, concentrated by lyophilisation, and then resuspended in Tris-HCl buffer (50 mM Tris-HCl, pH 8) and dialyzed against distilled water for $12 \mathrm{~h}$ and Tris-HCl buffer for $12 \mathrm{~h}$. Finally, the samples were stored at $-80^{\circ} \mathrm{C}$ until use.

Proteins were quantified using the method described by Bradford (Bradford, 1976) with bovine serum as a standard albumin. Twenty micrograms of crude ECPs was analyzed on a $10 \%$ SDSPAGE gel according to the method of Laemmli (Laemmli, 1970) and visualized by SYPRO Ruby staining (GelDoctм XR+ and ImageLabtм software, Biorad).

\subsection{Biochemical characterization of proteolytic activity of ECPs}

\subsubsection{Electrophoretic analyses}

Azocasein-gel zymography analysis was used to characterize proteolytic activity in the ECPs. One milliliter of a $5 \mathrm{mg} / \mathrm{ml}$ solution of azocasein, which had first been boiled for $20 \mathrm{~min}$, was copolymerized in $10 \%$ polyacrylamide gels for SDS-PAGE. Twenty micrograms of ECPs proteins were run under denaturing (SDS) and non-reducing conditions. After electrophoresis, the gel was washed with $2.5 \%$ Triton X-100 for $1 \mathrm{~h}$. This step allows the exchange of the SDS with Triton, after which the proteases recover their activity. Subsequently, the gel was incubated for $2 \mathrm{~h}$ at $22^{\circ} \mathrm{C}$ in $50 \mathrm{mM}$ Tris- $\mathrm{HCl}(\mathrm{pH}$ 8). Protein bands with azocaseinase activity were visualized after Coomassie blue staining of the gel.

SDS-PAGE was also used to demonstrate the digestive effect of crude ECPs on various types of protein substrates. Actin from bovine muscle, fibronectin from bovine plasma and collagen from oyster muscle were obtained from twenty $C$. gigas oysters using the method described by Mizuta et al. (Mizuta et al., 2005). Based on the method of Lee et al. (Lee et al., 2003), about $20 \mu \mathrm{g}$ of each substrate dissolved in $20 \mu \mathrm{l}$ of $50 \mathrm{mM}$ Tris-HCl pH 8 was added to $5 \mu \mathrm{g}$ of ECPs $(10 \mu \mathrm{l})$. After a $48 \mathrm{~h}$ of incubation at $22^{\circ} \mathrm{C}$, the reactions were stopped by adding cold $10 \%$ trichloroacetic acid (v/v) and the samples centrifuged at $12,000 \times \mathrm{g}$ for $10 \mathrm{~min}$. The supernatants were analyzed by SDS-PAGE using the Laemmli method (Laemmli, 1970) with $4 \%$ stacking gel and $10 \%$ resolving gel. All migrations were carried out at $170 \mathrm{~V}$ on a Mini-PROTEAN ${ }^{\circledR}$ Tetra Cell unit (Bio-Rad) and the gel visualized by Coomassie blue staining (GelDoc ${ }^{\mathrm{TM}} \mathrm{XR}+$ and ImageLabтм software, Biorad).

\subsubsection{Effect of inhibitors and metal ions on azocaseinase activity}


The proteolytic activity of ECPs from $V$. tubiashii 07/118 T2 was determined using azocasein as a substrate with a slightly modified version of the method developed by Teo et al. (Teo et al., 2003). Twenty five microliters of ECPs (initial protein concentration $\mathrm{Ci}=2.4 \mu \mathrm{g} / \mathrm{ml}$ ) and $25 \mu \mathrm{l}$ of Tris-HCl buffer was added to $50 \mu \mathrm{l}$ of azocasein $(5 \mathrm{mg} / \mathrm{ml}$ in $50 \mathrm{mM}$ Tris- $\mathrm{HCl}, \mathrm{pH}$ 8). The mixture was incubated at $22^{\circ} \mathrm{C}$ for 13 min in darkness and stirred constantly. The reaction was stopped by adding $100 \mu \mathrm{l}$ of $10 \%$ trichloroacetic acid $(\mathrm{v} / \mathrm{v})$. The mixture was centrifuged at $12,000 \times \mathrm{g}$ for $10 \mathrm{~min}$ and $50 \mu \mathrm{l}$ of the supernatant was added to $50 \mu \mathrm{l}$ of $1 \mathrm{M} \mathrm{NaOH}$ in 96 well plates (Nunc/Thermo Scientific). The optical density was measured at $440 \mathrm{~nm}$ in a microplate reader (Versamax, Molecular Devices).

The effect on protease activity of the following inhibitors was examined: 1,10 -phenantroline $\left(\mathrm{Zn}^{+2}\right.$ specific chelator); ethylenediamine tetraacetic acid (EDTA) (metal ion chelator); phenylmethanesulfonyl fluoride (PMSF) (serine protease inhibitor); and metal ions ( $\mathrm{MgSO}_{4}$, $\mathrm{CaCl}_{2}$ and $\mathrm{ZnCl}_{2}$ ). 1,10-phenantroline and PMSF were dissolved in a small volume of absolute ethanol (until total solubilization) and adjusted to the appropriate concentration with $50 \mathrm{mM}$ Tris$\mathrm{HCl} \mathrm{pH}$ 8, whereas EDTA and the different metal ions were directly dissolved in Tris-HCl Buffer. Briefly, after the preincubation of $25 \mu \mathrm{l}$ of each inhibitor at the appropriate concentration with 25 $\mu \mathrm{l}$ of ECPs at $22^{\circ} \mathrm{C}$, a $50 \mu \mathrm{l}$ of azocasein were added. All the mixtures were incubated at $22^{\circ} \mathrm{C}$ for $13 \mathrm{~min}$ and the reactions were terminated as described before. For two independent experiments, the residual protease activity was calculated as follows:

\section{Residual activity $(\%)=\Delta D o(+$ inhibitors or ions) $/ \Delta D o$ (without inhibitors or ions) $\mathrm{X} 100$}

\subsubsection{Effect of temperature and $\mathrm{pH}$ on azocaseinase activity}

The effect of temperature on the azocaseinase activity of 07/118 T2 ECPs was examined using azocasein as a substrate and the same protocol as described previously. Briefly, in this case, azocasein-ECPs mixtures were incubated at $4^{\circ} \mathrm{C}, 15^{\circ} \mathrm{C}, 22^{\circ} \mathrm{C}, 30^{\circ} \mathrm{C}, 37^{\circ} \mathrm{C}, 57^{\circ} \mathrm{C}$ and $100^{\circ} \mathrm{C}$. The samples were assayed in duplicate for each temperature.

The effect of $\mathrm{pH}$ on the protease activity of the ECPs was tested by an azocasein assay with the following modifications. Azocasein substrate $(5 \mathrm{mg} / \mathrm{ml})$ was dissolved in the appropriate $\mathrm{pH}$ buffer: Sodium acetate buffer ( $50 \mathrm{mM}$ ) for $\mathrm{pH} 3.7$ and 4.6; Sodium MES buffer (50 mM) for $\mathrm{pH}$ 5.6 and 6; MOPS sodium buffer $(50 \mathrm{mM})$ for $\mathrm{pH} 6.8$ and 7.5; Tris- $\mathrm{HCl}$ buffer $(50 \mathrm{mM})$ for $\mathrm{pH} 8$, 8.5 and 9; and Tris Base (50 mM) for $\mathrm{pH} 11$. Azocaseinase activity was measured in duplicate for each $\mathrm{pH}$ as previously described. The activities were calculated relative to the reaction at which the maximal activity was taken as $100 \%$.

$$
\text { Residual activity }(\%)=\Delta D o(X) / \Delta D o(\text { maximum activity) } \mathrm{X} 100
$$

\subsubsection{Metalloprotease activity assays with ADAM substrate}

Metalloprotease activity was tested using the ADAM substrate (Dabcyl-Leu-Ala-Gln-AlaHomophe-Arg-Ser-Lys(5-FAM)-NH2), supplied by Enzo $^{\circledR}$ Life Sciences (Dabcyl=4-(4dimethylaminophenylazo) benzoyl; FAM=carboxyfluorescein). The fluorescence intensity of the liberated FAM was measured in white 96 half well plates (Corning ${ }^{\circledR 3693)}$ using a BMG Labtech Fluostar Omega spectrofluorometer. The fluorescence was measured at $\lambda_{\mathrm{em}}=485 \mathrm{~nm}$ and $\lambda_{\mathrm{ex}}=520$ $\mathrm{nm}$. A stock solution of ADAM substrate at $6.5 \mathrm{mM}$ was first prepared in pure DMSO and then adjusted to the appropriate concentration with Tris-HCl buffer.

The same inhibitors and metal ions were tested for their effect on metalloprotease activity as described previously. In a final volume of $100 \mu \mathrm{l}, 25 \mu \mathrm{l}$ of crude ECPs $(2.4 \mu \mathrm{g} / \mathrm{ml})$ and $25 \mu \mathrm{l}$ of each inhibitor or metal ions at the appropriate concentration were incubated with $50 \mu$ of ADAM 
substrate at $10 \mu \mathrm{M}$, close to the apparent $\mathrm{Km}\left(\mathrm{Km}_{\text {app }}\right)$ value determined in preliminary experiments (data not shown). The reaction was conducted at $22^{\circ} \mathrm{C}$ for 13 min (fluorescence was measured every 8 seconds). For each inhibitor or metal ion, two independent experiments were performed and the residual ECPs metalloprotease activity was calculated according to the initial slope (Vi) of the assays run without inhibitors or ions.

Residual activity $(\%)=V i(+$ inhibitors or ions) / Vi (without inhibitors or ions) X 100

\subsection{Effect of extracellular products on hemocytes responses}

\subsubsection{Hemolymph sampling}

All experiments were performed using Pacific oysters $(8-12 \mathrm{~cm}$ ) from the same batch of oysters grown in Marennes Oléron (Establishments ROGER, Etaules). After reception, the oysters were stored at $4^{\circ} \mathrm{C}$ for a maximum of two days. Before the experiment, the oysters were well washed and immersed $30 \mathrm{~s}$ in ethanol $\left(70^{\circ}\right)$ to sanitize oyster and prevent hemolymph contamination during its extraction.

For each experiment, hemolymph from ten Pacific oysters was pooled for the flow cytometry analyses. For the extraction of hemolymph, a small notch was made in the dorsal side of the shell, adjacent to the adductor muscle. Using a $1 \mathrm{ml}$ plastic syringe fitted with a 23 gauge needle, approximately $1.5 \mathrm{ml}$ of whole hemolymph was withdrawn from the adductor muscle of individual oysters, filtered through $40 \mu \mathrm{m}$ mesh and immediately placed in ice to minimize cell clumping. After collecting the hemolymph, the integrity and number of hemocytes was checked by light-microscopic observations on a Malassez hemocytometer.

\subsubsection{Assays measuring hemocyte cellular parameters}

The effect of ECPs on cell viability, phagocytosis, intra-cytoplasmic calcium, esterase activity, the presence of lysosomes and adhesion capacity was assessed by referring to the study described by Gagnaire et al. (Gagnaire et al., 2003).

Hemocytes were analysed with a BD Biosciences FACSCanto ${ }^{\mathrm{TM}}$ II flow cytometer and FACSDiva Software Version 6.1.3. For each test, 10000 events were counted and the results were expressed as cell cytograms indicating cell size (FSC value: Forward Scatter Height), cell complexity (SSC value: Size Scatter Height) and the fluorescence channel(s) corresponding to the marker used.

For all tests, the osmolarity of the samples was set at $1,000 \mathrm{mosm} / \mathrm{l}$ to approximate seawater osmolality by the adding of an equivalent quantity of $\mathrm{NaCl}$ and after the osmolarity was checked using a cryoscopic osmometer (Roebling).

For adhesion capacity, $150 \mu \mathrm{l}$ of ECPs at a final protein concentration of $6 \mu \mathrm{g} / \mathrm{ml}$ were added to $150 \mu \mathrm{l}$ of hemolymph (approximately 80, $000 \mathrm{cell} /$ well). After a $3 \mathrm{~h}$ of incubation at $22^{\circ} \mathrm{C}$, the cells were fixed by addition of $150 \mu \mathrm{l}$ of formalin (6\% v/v) (Labreuche et al., 2006a). The percentage of non adherent hemocytes was calculated relative to the initial total hemocytes count at $\mathrm{t}=0 \mathrm{~min}$. SASW and Tris-HCl Buffer were used as a control.

For cell mortality, phagocytosis activity, esterase activity, the presence of lysosomes and intracytoplasmic calcium activity were tested at different times of incubation (1 h, $2 \mathrm{~h}, 4 \mathrm{~h}$ and $6 \mathrm{~h}$ ). Briefly, for each activity, $100 \mu \mathrm{l}$ of a hemocyte suspension were added to $100 \mu \mathrm{l}$ of ECPs at a final concentration of $6 \mu \mathrm{g}$ proteins per $\mathrm{ml}$ in flow cytometer tubes then incubated at $22^{\circ} \mathrm{C}$ under agitation in the dark, when specific probes were added. Cell mortality was quantified using $10 \mu \mathrm{l}$ of propidium iodide (IP) at a concentration of $0.5 \mathrm{mg} / \mathrm{ml}$. Phagocytosis was measured by ingestion of $10 \mu \mathrm{l}$ of fluorescent beads (FluoSpheres ${ }^{\circledast}$ Carboxylate-Modified Microspheres, $1.0 \mu \mathrm{m}$ ) diluted 1/10 with pure water. Esterase activity was evaluated by Fluorescein Diacetate substrate (FDA) and the presence of lysosomes was assayed with Lysotracker (LysoTracker ${ }^{\circledast}$ Green DND-26). For both analyses, the reaction was stopped after $5 \mathrm{~min}$ by placing in ice. The detection of 
intracytoplasmic calcium was carried out with Fluo-4, AM (Fluo-4, AM, cell permeant, Molecular Probes $^{\circledR}$ ). For all tests, SASW and Tris-HCl Buffer were used as a control.

For esterase, lysosome and intracytoplasmic calcium, the percentage of cells with high enzymatic activities was defined on the basis of the most strongly fluorescent cells (percentage of cells showing the strongest fluorescence) among all cells.

\subsection{Mass spectrometry analyses}

Mass spectrometry analyses of ECPs from $V$. tubiashii 07/118 T2 were performed by the "Structural and Functional Mass Spectrometry Facility" in the JACQUES MONOD Institute (CNRS and Paris-Diderot University). ECPs were analyzed by a LTQ Velos Orbitrap (Thermo Fisher Scientific, San Jose, CA) coupled to an Easy nano-LC Proxeon system (Thermo Fisher Scientific, San Jose, CA). Chromatographic separation of peptides was performed with the following parameters : column Easy Column Proxeon C18 (10 cm, $75 \mu$ m i.d., 120 A), 300 $\mathrm{nl} / \mathrm{min}$ flow, gradient rising from $95 \%$ solvent A (water - $0,1 \%$ formic acid) to $25 \%$ solvent $\mathrm{B}$ (100\% acetonitrile, $0,1 \%$ formic acid) in 20 minutes, then to $45 \%$ with solvent B in 40 min and finally to $80 \%$ with solvent B in 10 min. Peptides were analyzed in the orbitrap in full ion scan mode at a resolution of 30, 000 and a mass range of $400-1800 \mathrm{~m} / \mathrm{z}$. Fragments were obtained with a collision-induced dissociation (CID) activation with a collisional energy of $40 \%$ and analyzed in the LTQ. MS/MS data were acquired in a data dependent mode in which 20 most intense precursor ions were isolated, with a dynamic exclusion of $15 \mathrm{~s}$, an isolation width of 1 Dalton, an activation of 0.250 for $10 \mathrm{~ms}$. Maximum injection time were set to $100 \mathrm{~ms}$ for MS and $50 \mathrm{~ms}$ for MS/MS analysis. Data were processed with Proteome Discoverer 1.3 software (Thermo Fisher scientific, San Jose, CA) coupled to an in house Mascot search server (Matrix Science, Boston, $\mathrm{MA}$; version 2.3.2). The mass tolerance of fragment ions was set to $10 \mathrm{ppm}$ for precursor ions and 0.6 Dalton for fragments. The following modifications were used in variable modifications: oxidation (M), phosphorylations (STY). The maximum number of missed cleavages was limited to 2 for trypsin digestion. MS-MS data were searched against NCBInr database and V. tubiashii ATCC 19109genome NCBI database. Peptide validator node was used for False Discovery Rate (FDR) determination and a $1 \%$ threshold was used for the validation of peptide identification.

\subsection{Sequencing of the metalloprotease gene, functional annotation and phylogenetic analysis}

Primer 3 software (http://frodo.wi.mit.edu) was used to design PCR primers of the metalloprotease gene based on the V. tubiashii ATCC 19109_25 whole genome sequence (GI=343500308). After extraction of $V$. tubiashii 07/118 T2 DNA using the standard phenol/chloroform/isoamyl-alcohol method, genomic DNA was amplified using two couples of

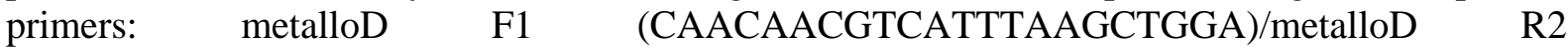
(ACCGAAGTAGTGAGCGTCGT) and metalloD (AGTGCAAGCTGGAAAATGCT)/metalloNc R1 (TACTCGTCGTTGGTTTGCTG). A PCR reaction was performed using Diamond Taq ${ }^{\circledast}$ DNA polymerase according to the manufacturer's instructions in a Gene Amp PCR System 2700 (Applied Biosystems). The PCR procedure was as follows: initial denaturation at $95^{\circ} \mathrm{C}$ for $3 \mathrm{~min}$ and 35 cycles of $1 \mathrm{~min}$ at $95^{\circ} \mathrm{C}, 1 \mathrm{~min}$ at $55^{\circ} \mathrm{C}$ and $2 \mathrm{~min}$ at $72^{\circ} \mathrm{C}$ followed by an additional $10 \mathrm{~min}$ at $72^{\circ} \mathrm{C}$.

The amplicons with the expected size were purified using an Amicon Ultra centrifugal filter from Millipore (30 kDa). The purified PCR products were mixed (final volume $10 \mu \mathrm{l}$ ) with $0.4 \mu \mathrm{l}$ ABI Prism Big Dye Terminator ready reaction mix (Applied Biosystems) and $4 \mu \mathrm{M}$ of primer. Cycle sequencing reactions were performed using a Gene Amp PCR System 2700 (Applied Biosystems) following the manufacturer's instructions. Separation of the DNA fragments was carried out in an ABI PRISM 3100 Genetic Analyzer (Applied Biosystems). The sequence data for the metalloprotease 1 gene was submitted to the GenBank database under accession number KF270512. 
The metalloprotease sequence annotation was determined by ExPASy - PROSITE (http://prosite.expasy.org/mydomains/), and NetPhosbac (http://www.cbs.dtu.dk/services/NetPhosBac/). The signal peptide cleavage sites were predicted by the SignalP 4.1 Server (http://www.cbs.dtu.dk/services/SignalP/) and the physical and chemical parameters by ExPASy ProtParam (http://expasy.org/tools/protparam.html).

For Vibrio metalloprotease phylogenetic comparison, metalloprotease sequences were aligned using ClustalW (http://www.ebi.ac.uk/Tools/msa/clustalw2/) and BioEdit software (http://www.mbio.ncsu.edu/bioedit/bioedit.html).

Afterwards, a phylogenetic tree was built using Mega6 software (Tamura et al., 2013) The tree was drawn using the Neighbor-Joining method (Saitou and Nei, 1987). Reliability of topologies was assessed by the bootstrap method (Felsenstein, 1985) with 1000 replicates. The Genbank accession numbers of Vibrio metalloproteases are presented in Supplementary Table 1.

\subsection{Statistical analysis}

For each hemocyte activity assay, statistical analysis was performed using Xlstat software and http://marne.u707.jussieu.fr/biostatgv/. Technical replicates $(n=3)$ were averaged and the values were tested for normality (Shapiro-Wilk). Data originating from three hemolymph pools from ten animals $(\mathrm{N}=3)$ were analyzed by a paired Friedman test.

\section{Results}

\subsection{V. tubiashii secretes various proteins with digestive activities}

Analysis of crude ECPs using SDS polyacrylamide gel electrophoresis revealed a rich protein profile (Fig. 1A). Several bands were detected with apparent molecular weights between 100 and $20 \mathrm{kDa}$, with three more intense bands estimated at $60 \mathrm{kDa}, 41 \mathrm{kDa}$ and $36 \mathrm{kDa}$. Azocasein zymography showed a remarkable degradation profile. A trail of substrate digestion was observed from the top of the gel to nearly $55 \mathrm{kDa}$ and another halo of digestion with apparent molecular weights of more than $40 \mathrm{kDa}$ (Fig. 1A). Moreover, the digestion of protein substrates by crude ECPs from 07/118 T2 was observed. The results showed that ECPs were able to degrade collagen extracted from oysters (Fig. 1B) as actin, fibronectin from bovine source (data not shown). SDSPAGE analyses showed the same pattern of digestion for the different substrates, i.e. the disappearance of parent proteins.

\subsection{Evidences of hemocytes impairment by crude ECPs}

The impact of ECPs secreted by V. tubiashii 07/118 T2 was evaluated following in vitro contact with $C$. gigas hemocytes. Different cellular immune functions were tested with flow cytometry: cellular mortality, phagocytosis activity, adhesion capacity, esterase and intra cytoplasmic calcium activity, and finally the presence of lysosomes. A significant inhibition of adhesion capacity $(\mathrm{p}<0.05)$ was observed, as shown in Figure 2 . Around $28 \%$ of adhesion capacity was lost after $3 \mathrm{~h}$ incubation with ECPs at $6 \mu \mathrm{g}$ ml-1 of proteins compared to the SASW and Tris- $\mathrm{HCl}$ buffer controls.

Similarly, a significant inhibition in phagocytic activity was detected as early as the first hour of incubation $(\mathrm{p}<0.05)$. Around $56 \%$ of hemocyte phagocytic activity was lost following contact with ECPs at $6 \mu \mathrm{g} / \mathrm{ml}$ compared to controls (hemocytes incubated with SASW or Tris-HCl buffer) (Fig. 2B). This decrease was constant over time, even after $6 \mathrm{~h}$ of incubation. For the other cellular functions like cell mortality, intra-cytoplasmic free calcium, esterase activity and the presence of lysosomes, no significant effect was observed ( $\mathrm{p}>0.05$ ) (data not shown).

\subsection{Biochemical characterizations of the proteolytic fraction of ECPs}




\subsubsection{Evidences of the presence of zinc metalloprotease(s) in ECPs}

ECPs had demonstrable proteolytic activity when azocasein was used as a substrate. The addition of metal chelating agents into the reaction mix, like EDTA and 1, 10-phenanthroline inhibited azocaseinase activity (Table 1A). This proteolytic activity was much more inhibited by 1, 10phenanthroline (18.1\% residual activity with $0.5 \mathrm{mM}$ f.c.) than by EDTA (72.9\% residual activity with $10 \mathrm{mM}$ f.c.) which is known to be less selective and affine zinc chelator than 1, 10phenanthroline.

The effect of biologically relevant metal ions on the proteolytic activity of ECPs was also investigated (Table 1A). Azocaseinase activity was strongly affected by the addition of $\mathrm{Zn}^{2+}$ ions, with a loss of $50 \%$ of the proteolytic activity. However, the addition of $\mathrm{Mg}^{2+}$ and $\mathrm{Ca}^{2+}$ ions at the same concentration as $\mathrm{Zn}^{2+}$ had little effect on enzymatic activity.

To confirm that the proteolytic fraction contains metalloprotease(s), a more specific substrate was used (ADAM substrate). In this case, hydrolytic cleavage of this specific substrate by crude ECPS attested of the presence of metalloprotease(s) activity in ECPs, inhibited by more than $75 \%$ by 1 , 10 -phenanthroline and also reduced by $22 \%$ in the presence of EDTA (Table 1B). Moreover, in opposite to the results obtained with azocasein assays, the addition of PMSF into the reaction mix affected hydrolytic cleavage of the ADAM substrate (Table 1B).

For metal ions, the addition of $\mathrm{Zn}^{2+}$ decreased metalloprotease activity by $75 \%$ while the addition of $\mathrm{Ca}^{2+}$ and $\mathrm{Mg}^{2+}$ did not affect ADAM substrate hydrolysis (Table 1B).

\subsubsection{Evidences of a thermostable proteolytic activity with an alkaline optimum pH}

The effect of temperature on azocaseinase activity is shown in figure 3A. Azocaseinase activity was still detected over a wide temperature range, between $4^{\circ} \mathrm{C}$ and $57^{\circ} \mathrm{C}$, while a loss of more than $50 \%$ of the activity was observed at $100^{\circ} \mathrm{C}$. The optimum temperature for the proteolytic activity of the ECPs was $57^{\circ} \mathrm{C}$.

The effect of $\mathrm{pH}$ on proteolytic activity was tested using buffers with a $\mathrm{pH}$ ranging from 4.6 to 12 . Azocaseinase activity was exceptionally stable between $\mathrm{pH} 5.6$ and 11 (Fig. 3B) with an optimum at $\mathrm{pH}$ 8. Since the catalytic mechanism of zinc metalloproteases is a typical base catalysis reaction that involves the bound water molecule being polarized by a Glu (Glutamic acid) residue (Kontogiorgis et al., 2005), a radical drop in protease activity was to be expected and was indeed observed at $\mathrm{pH} 4.6$ and $\mathrm{pH} 12$.

\subsection{Evidences of a highly present zinc metalloprotease belonging to the thermolysin family in V. tubiashii ECPs}

Mass spectrometry Orbitrap analyses evidenced the presence of an "Extracellular zinc metalloprotease" (GI: 343500312) in V. tubiashii 07/118 T2 ECPs, with a score of 385.48 and coverage of $8.9 \%$ with semiTrypsin analysis, and a score of 3668.01 and a coverage of $32.62 \%$ with no enzyme analysis (Table 2). An extracellular $\mathrm{N}$-acetylglucosamine-binding protein was also detected with none (no enzyme) analysis (Table 2).

The gene encoding the extracellular zinc metalloprotease identified in mass spectrometry analyses was sequenced and resulted in a 1821 bp product (accession number AHG50771). Vibrio metalloproteases phylogenetic analyses revealed that 07/118 T2 metalloprotease was close to predicted extracellular zinc metalloproteases of both $V$. tubiashii LMG 19109T (accession no. EGU55378) and LMG 19106 (accession no. EIF02000). However, the 07/118 T2 metalloprotease is distant from VtpA and VtpB (two V. tubiashii RE 22 metalloproteases) with $82 \%$ and $50 \%$ similarity, respectively (Fig. 5).

The deduced metalloprotease amino-acid sequence contain the zinc-binding consensus sequence $(\mathrm{HEXXH})=\left(\mathrm{H}^{342} \mathrm{EVSH}^{346}\right)$, which is typical of the zincins metalloprotease superfamily (Hooper, 
1994; Miyoshi and Shinoda, 2000a). It also contains the potential third zinc ligand located 19 bases downstream from the second histidine of the zinc-binding motif (HEXXH 19aa GXXNEXXSD) that corresponds to ( $\mathrm{H}^{342} \mathrm{EVSH}^{346} \sim 19 \mathrm{aa} \sim \mathrm{GGINE}{ }^{366} \mathrm{AFSD}$ ), which characterizes the thermolysin family (EC 3.4.24.27) (Hooper, 1994; Miyoshi and Shinoda, 2000a; Miyoshi et al., 2002) (Fig. 4).

$V$. tubiashii 07/118 T2 metalloprotease has a predicted molecular weight of $66 \mathrm{kDa}$ and a putative signal sequence containing 25 amino acids with a potential signal peptidase cleavage site between Ala 25 and Ala 26 (Fig. 4). This signal peptide is followed by a protein with a predicted molecular mass of $63.25 \mathrm{kDa}$ and a predicted isoelectric point of 5.22.

A prosite algorithm revealed the presence of an $\mathrm{N}$-myristoylation site (13 sites) and an $\mathrm{N}$ glycosylation site (8 sites). NetPhosbact revealed 14 potential sites of phosphoryation: serine (13) and threonine (1).

\section{Discussion}

As we had previously demonstrated the virulence of $V$. tubiashii $07 / 118 \mathrm{~T} 2$ and the toxicity of their ECPs on juvenile oysters (Travers et al., 2014), in this study we now assessed host cellular immune responses and bacterial potential effectors by which these ECPs can be associated with the virulence of this strain. The main objective of this work was to achieve a biochemical and molecular identification of these toxic ECPs coupled with the evaluation of their biological activities by (1) the identification of exoproteolytic fraction using electrophoretic, enzymatic, molecular and mass spectrometry analyses, (2) the determination of the effect of ECPs on the cellular immune response of the oyster.

\subsection{Hemocyte impairments when exposed to ECPs produced by $V$. tubiashii 07/118 T2}

Even if the impact of ECPs on C. gigas hemocytes was previously investigated in other interaction models (Allam and Ford, 2006; Hégaret et al., 2003; Labreuche et al., 2010; Paillard et al., 2004), no information concerning $V$. tubiashii secreted proteins on oyster immune cells is currently available. It is even more important to fill this gap with the recent identification of a distinct group of $V$. tubiashii strains in France (Travers et al., 2014).

In this study, the hemocytes of $C$. gigas were used as a biological model to demonstrate ECPs cytotoxicity to oyster hemocytes in in vitro conditions. Crude ECPs from V. tubiashii 07/118 T2 reduced by $28 \%$ the adhesive capacity of $C$. gigas hemocytes 3 h post-incubation. Consequently, phagocytic activity, one of the most important immune functions in bivalves (Cheng and Sullivan, 1984; Matozzo et al., 2007; Prado-Alvarez et al., 2012), was reduced by almost 56\% within the first hours of incubation. No significant effect was detected on cell mortality, intra-cytoplasmic calcium, esterase activity and the presence of lysosomes.

The decrease in adhesion capacity and consequently in the phagocytic activity of hemocytes is often observed either with other species of Vibrio or their extracellular products. For M. edulis hemocytes, cell rounding was observed within 2 to $3 \mathrm{~h}$ post challenge by $V$. alginolyticus and $V$. anguillarum (Lane and Birkbeck, 2000, 1999). It was also reported that the loss of pseudopodia and the morphological changes in $V$. philippinarum hemocytes led to a loss of adherence capacity after incubation with $V$. tapetis (Choquet et al., 2003). The same morphological changes were observed with $V$. aestuarianus 01/32 with C. gigas hemocytes (Labreuche et al., 2006b) and $V$. splendidus with $M$. arenaria hemocytes (Araya et al., 2009; Mateo et al., 2009). Similar morphological damage to hemocytes was also described with Vibrio ECPs. Labreuche et al. demonstrated that $16 \mu \mathrm{g} / \mathrm{ml}$ of ECPs from $V$. aestuarianus could cause a reduction in adhesion capacity (almost 21\% of inhibition) and an inhibition of phagocytic activity (30\% of inhibition) when placed in contact with C. gigas hemocytes (Labreuche et al., 2006a). All these observations comforted the results obtained with 07/118 T2 ECPs on adhesion and phagocytic activity of adult 
oyster hemocytes. Furthermore, it would be interested to confirm our results on hemocytes sampled from the most affected age class (i.e. hemocytes from spat oyster).

The mechanism by which bacteria cause cell rounding and inhibit further phagocytosis was only poorly described in previous studies (Araya et al., 2009; Brulle et al., 2012; Labreuche et al., 2006b; Lane and Birkbeck, 1999).

In our study, the hydrolytic action of $V$. tubiashii 07/118 T2 ECPs was assayed directly on purified structural proteins extracted from oysters. We showed that extracellular effectors degraded muscle collagen and also bovine actin and fibronectin proteins (data not shown). Indeed, the cleavage of these proteins, which are essential in extracellular matrix formation or are involved in the phagocytic process (May and Machesky, 2001; Proctor et al., 1985) and in cell adhesion, chemotaxis and migration (Koutsogiannaki and Kaloyianni, 2011), might potentially affect hemocyte immune responses. It was reported that an alteration of actin rearrangement by a pathogen might protect it from being neutralized by phagocytic cells (May and Machesky, 2001). Using fluorescence microscopy, Moore et al. (Moore et al., 1992) showed that the rounding of $M$. arenaria hemocytes is caused by an alteration in cytoskeletal architecture induced by a damage of actin filaments.

\subsection{Molecular evidences of thermostable metalloprotease(s) in $V$. tubiashii 07/118 T2 secretome}

To achieve a biochemical and molecular identification of these toxic ECPs, crude ECPs were analyzed by coupling electrophoretic, enzymatic, molecular and mass spectrometry analyses. Firstly, a set of biochemical assays was carried out on ECPs. SDS-PAGE analysis showed a rich protein profile with different molecular weights. Azocasein zymogram showing regions of clearing indicated the presence of proteolytic activities. Comparing the two results, we observed a big smear which ended with the major protein (a band around $55 \mathrm{kDa}$ ) detected on SDS-PAGE and an individual digestion band that coincided with other high intensity bands detected with SDS-PAGE (bands between 37 and $50 \mathrm{kDa}$ ). It seems that several other proteases, or one protease with different post-translational processing, may be present but could not be visualized due to the smearing of the hydrolytic activity.

Furthermore, the effect of inhibitors and metal ions was tested using azocasein, a non-specific protease substrate, and the ADAM substrate, which is usually used to monitor disintegrin and metalloproteinase activity (Jacobsen et al., 2008; Ochoa-Campuzano et al., 2007).

The results obtained with these two tests showed that the protease activity in 07/118 T2 ECPs was inhibited by the zinc-specific chelator, 1, 10-phenanthroline (about $80 \%$ of the total protease activity was inhibited). Also, the addition of the $\mathrm{Zn} 2+$ ion strongly affected protease activity. It has been demonstrated that high zinc concentrations inhibit metalloprotease activity through the formation of the zinc monohydroxide $(\mathrm{Zn}(\mathrm{OH})+)$ that bridges the catalytic zinc ion to the side chain of the active site of the enzyme (Larsen and Auld, 1991). The results obtained are further proof of the high representation of zinc metalloprotease activity in the ECPs of 07/118 T2.

However, a decrease in proteolytic activity was observed when PMSF (a serine protease inhibitor) and the ADAM substrate were associated, while such phenomenon was not detected with the azocasein substrate. This result does not negate the presence of zinc metalloprotease activity but suggests a non-specific reaction of PMSF with the active site of the metalloprotease or with the ADAM substrate. However, the first hypothesis was dismissed because no inhibition was observed with the azocaseinase assay. The ADAM substrate used contains a single serine residue in its primary structure (Dabcyl-Leu-Ala-Gln-Ala-Homophe- Arg-Ser-Lys (5-FAM)-NH2) so it is possible that PMSF could covalently fix this serine, making the ADAM substrate non-cleavable. A large folded protein like azocasein, should be less in favor to non-specific PMSF fixation, even if it contains about $5.9 \%$ of serine residues (Ellinger and boyne, 1965).

Moreover, ECPs proteases showed a fairly wide range of $\mathrm{pH}$, from 5.6 to 11, with an optimum at $\mathrm{pH}$ 8. It was previously reported that the metalloproteases secreted by marine bacteria are usually 
alkaline proteases; they have an alkaline optimum $\mathrm{pH}$ and are stable within an alkaline range (Wu and Chen, 2011). In relation to temperature, ECPs proteases demonstrated a proteolytic activity from $4^{\circ} \mathrm{C}$ to $100^{\circ} \mathrm{C}$ with an optimum at $57^{\circ} \mathrm{C}$. It should be mentioned that a loss of only $50 \%$ of protease activity was observed at $100^{\circ} \mathrm{C}$. This performance over a wide range of temperatures and $\mathrm{pH}$ tends to confirm the idea that proteolytic fraction of ECPs contains thermostable active zinc metalloprotease(s) (Kudryashova et al., 1998).

By liquid chromatography coupled with mass spectrometry, an extracellular zinc metalloprotease (GI: 343500312) was identified and the gene encoding this protein was sequenced in $V$. tubiashii $07 / 118$ T2. Annotation of the gene encoding this exometalloprotease showed that this enzyme is a member of the thermolysin family (EC 3.4.24.27) (Miyoshi and Shinoda, 2000a; Miyoshi et al., 2002). In addition, glycosylation and phosphorylation motifs were identified on the metalloprotease sequence. The presence of these motifs suggested that the 07/118 T2 metalloprotease could be subject to post-translational modifications which can enable it to perform functions other than those determined by its primary sequence (Ahmad et al., 2007). Furthermore, it was shown that the HEXXH metalloprotease family is the only family of this protease group that is extensively modified post-translationally by both $\mathrm{N}$ glycosylation and glycosyl phosphatidylinositol (McGwire and Chang, 1996).

Moreover, based on the phylogenetic tree, a large distance between the 07/118 T2 metalloprotease and the American V. tubiashii RE22 metalloproteases VtpA and VtpB (Hasegawa \& Häse, 2009b; Hasegawa et al., 2008) were observed. This data could suggest that the 07/ 118 T2 metalloprotease is different from the metalloproteases of the American strains previously described as major virulence factors.

In fact, proteases are generally described as one of the factors that are most toxic to the host, and are involved in virulence and pathogenicity (Shinoda et al., 1996). Most of these proteases have been identified as zinc metalloproteases (Miyoshi and Shinoda, 2000b). Studies on $V$. aestuarianus metalloprotease (Vam) showed its toxicity and its capacity to impair oyster hemocyte functions (Labreuche et al., 2010). A metalloprotease from V. splendidus for pacific oyster C. gigas (Vsm) has been shown to be the major factor in the toxicity of the ECPs (Binesse et al., 2008). Extracellular products from $V$. tubiashii were also shown to be toxic to oyster larvae and its pathogenicity was linked to a metalloprotease (VtpA) and a hemolysin (VthA) (Delston et al., 2003; Hasegawa and Häse, 2009a; Hasegawa et al., 2008; Kothary et al., 2001).

\section{Conclusions}

It had previously been shown that the ECPs produced by $V$. tubiashii 07/118 T2 were toxic for juvenile oysters in experimental challenges. In this study, it was shown that these toxic ECPs could inhibit hemocytes adhesion capacity and phagocytosis activity, and digest matrix host proteins. the proteolytic fraction of ECPs contained active and thermostable extracellular zinc metalloprotease(s) and a thermolysin.

Even if taken together, our results let us wonder if this (these) zinc metalloprotease(s) could be involved in the impairment of hemocyte immunological functions, the direct implication of this protein in ECPs toxicity still has to be demonstrated.

\section{Acknowledgements}

This study was supported by a Ph.D grant from the CNRS and IFREMER for R. Mersni-Achour (2010-2013). The PRES (Pôle de Recherche et d'Enseignement Supérieur) of the Limousin and Poitou-Charentes regions and the FR CNRS 3097 «Fédération de Recherche en Environnement et Développement Durable» are acknowledged for their financial support through the research project «Caractérisation in vitro des effets de métalloprotéases sur différents types cellulaires de l'huître creuse $C$. gigas». Special thanks go to L. Beaugeard, for technical assistance during the 
flow cytometer analyses. Thanks go to the platform "Structural and Functional Mass Spectrometry Facility, Jacques Monod Institute, UMR7592 CNRS - Univ Paris Diderot, Sorbonne Paris Cité" and especially to T. Léger and C. Garcia for mass spectrometry analysis. Acknowledgment also goes to M. Francis Healy for his revision of the English language.

\section{REFERENCES}

Ahmad, I., Hoessli, D.C., Gupta, R., Walker-Nasir, E., Rafik, S.M., Choudhary, M.I., Shakoori, A.R., Nasir-ud-Din, 2007. In silico determination of intracellular glycosylation and phosphorylation sites in human selectins: Implications for biological function. J. Cell. Biochem. 100, 1558-1572.

Allam, B., Ford, S.E., 2006. Effects of the pathogenic Vibrio tapetis on defence factors of susceptible and non-susceptible bivalve species: I. Haemocyte changes following in vitro challenge. Fish Shellfish Immunol. 20, 374-383.

Araya, M.T., Siah, A., Mateo, D.R., Markham, F., McKenna, P., Johnson, G.R., Berthe, F.C.J., 2009. Morphological and Molecular Effects of Vibrio splendidus on Hemocytes of Softshell Clams, Mya arenaria. J. Shellfish Res. 28, 751-758.

Binesse, J., Delsert, C., Saulnier, D., Champomier-Vergès, M.-C., Zagorec, M., Munier-Lehmann, H., Mazel, D., Roux, F.L., 2008. Metalloprotease Vsm Is the Major Determinant of Toxicity for Extracellular Products of Vibrio splendidus. Appl. Environ. Microbiol. 74, 7108-7117.

Bradford, M.M., 1976. A rapid and sensitive method for the quantitation of microgram quantities of protein utilizing the principle of protein-dye binding. Anal. Biochem. 72, 248-254.

Broberg, C.A., Calder, T.J., Orth, K., 2011. Vibrio parahaemolyticus cell biology and pathogenicity determinants. Microbes Infect. 13, 992-1001.

Brulle, F., Jeffroy, F., Madec, S., Nicolas, J.-L., Paillard, C., 2012. Transcriptomic analysis of Ruditapes philippinarum hemocytes reveals cytoskeleton disruption after in vitro Vibrio tapetis challenge. Dev. Comp. Immunol. 38, 368-376

Cheng, T.C., Sullivan, J.T., 1984. Effects of heavy metals on phagocytosis by Molluscan hemocytes. Mar. Environ. Res. 14, 305-315.

Choquet, G., Soudant, P., Lambert, C., Nicolas, J., Paillard, C., 2003. Reduction of adhesion properties of Ruditapes philippinarum hemocytes exposed to Vibrio tapetis. Dis. Aquat. Organ. 57, 109-116.

Delston, R.B., Kothary, M.H., Shangraw, K.A., Tall, B.D., 2003. Isolation and characterization of a zinc-containing metalloprotease expressed by Vibrio tubiashii. Can. J. Microbiol. 49, 525-529.

Duperthuy, M., Binesse, J., Le Roux, F., Romestand, B., Caro, A., Got, P., Givaudan, A., Mazel, D., Bachère, E., Destoumieux-Garzón, D., 2010. The major outer membrane protein OmpU of Vibrio splendidus contributes to host antimicrobial peptide resistance and is required for virulence in the oyster Crassostrea gigas. Environ. Microbiol. 12, 951-963.

Duperthuy, M., Schmitt, P., Garzón, E., Caro, A., Rosa, R.D., Roux, F.L., Lautrédou-Audouy, N., Got, P., Romestand, B., Lorgeril, J. de, Kieffer-Jaquinod, S., Bachère, E., Destoumieux-Garzón, D., 2011. Use of OmpU porins for attachment and invasion of Crassostrea gigas immune cells by the oyster pathogen Vibrio splendidus. Proc. Natl. Acad. Sci. 201015326.

Ellinger, G.M., Boyne, E.B., 1965. Amino acid composition of some fish products and casein. Br. J. Nutr. 19, 587-592.

Elston, R.A., Hasegawa, H., Humphrey, K.L., Polyak, I.K., Häse, C.C., 2008. Re-emergence of Vibrio tubiashii in bivalve shellfish aquaculture: severity, environmental drivers, geographic extent and management. Dis. Aquat. Organ. 82, 119-134.

Felsenstein, J., 1985. Confidence Limits on Phylogenies: An Approach Using the Bootstrap. Evolution 39, 783.

Gagnaire, B., Renault, T., Bouilly, K., Lapegue, S., Thomas-Guyon, H., 2003. Study of atrazine effects on Pacific oyster, Crassostrea gigas, haemocytes. Curr. Pharm. Des. 9, 193-199. 
Garnier, M., Labreuche, Y., Nicolas, J.-L., 2008. Molecular and phenotypic characterization of Vibrio aestuarianus subsp. francensis subsp. nov., a pathogen of the oyster Crassostrea gigas. Syst. Appl. Microbiol. 31, 358-365.

Hada, H.S., West, P.A., Lee, J.V., Stemmler, J., Colwell, R.R., 1984. Vibrio tubiashii sp. nov., a Pathogen of Bivalve Mollusks. Int. J. Syst. Bacteriol. 34, 1-4.

Hasegawa, H., Häse, C.C., 2009. The extracellular metalloprotease of Vibrio tubiashii directly inhibits its extracellular haemolysin. Microbiology 155, 2296-2305.

Hasegawa, H., Lind, E.J., Boin, M.A., Häse, C.C., 2008. The Extracellular Metalloprotease of Vibrio tubiashii Is a Major Virulence Factor for Pacific Oyster (Crassostrea gigas) Larvae. Appl. Environ. Microbiol. 74, 4101-4110.

Hégaret, H., Wikfors, G.H., Soudant, P., 2003. Flow cytometric analysis of haemocytes from eastern oysters, Crassostrea virginica, subjected to a sudden temperature elevation: II. Haemocyte functions: aggregation, viability, phagocytosis, and respiratory burst. J. Exp. Mar. Biol. Ecol. 293, 249-265.

Hooper, N.M., 1994. Families of zinc metalloproteases. FEBS Lett. 354, 1-6.

Jacobsen, J., Visse, R., Sørensen, H.P., Enghild, J.J., Brew, K., Wewer, U.M., Nagase, H., 2008. Catalytic properties of ADAM12 and its domain deletion mutants. Biochemistry (Mosc.) 47, 537547.

Jeffries, V.E., 1982. Three Vibrio strains pathogenic to larvae of Crassostrea gigas and Ostrea edulis. Aquaculture 29, 201-226.

Kontogiorgis, C.A., Papaioannou, P., Hadjipavlou-Litina, D.J., 2005. Matrix metalloproteinase inhibitors: a review on pharmacophore mapping and (Q)SARs results. Curr. Med. Chem. 12, 339355.

Kothary, M.H., Delston, R.B., Curtis, S.K., McCardell, B.A., Tall, B.D., 2001. Purification and Characterization of a Vulnificolysin-Like Cytolysin Produced by Vibrio tubiashii.Appl. Environ. Microbiol. 67, 3707-3711.

Koutsogiannaki, S., Kaloyianni, M., 2011. Effect of $17 \beta$-estradiol on adhesion of Mytilus galloprovincialis hemocytes to selected substrates. Role of alpha2 integrin subunit.Fish Shellfish Immunol. 31, 73-80.

Kudryashova, E.V., Mozhaev, V.V., Balny, C., 1998. Catalytic activity of thermolysin underextremes of pressure and temperature: modulation by metal ions. Biochim. Biophys.Acta BBA - Protein Struct. Mol. Enzymol. 1386, 199-210.

Labreuche, Yannick, Lambert, C., Soudant, P., Boulo, V., Huvet, A., Nicolas, J.-L., 2006 b.Cellular and molecular hemocyte responses of the Pacific oyster, Crassostrea gigas,following bacterial infection with Vibrio aestuarianus strain 01/32. Microbes Infect. 8,2715-2724.

Labreuche, Y., Le Roux, F., Henry, J., Zatylny, C., Huvet, A., Lambert, C., Soudant, P.,Mazel, D., Nicolas, J.-L., 2010. Vibrio aestuarianus zinc metalloprotease causeslethality in the Pacific oyster Crassostrea gigas and impairs the host cellular immunedefenses. Fish Shellfish Immunol. 29, 753-758.

Labreuche, Y., Soudant, P., Goncalves, M., Lambert, C., Nicolas, J., 2006 a. Effects of extracellular products from the pathogenic Vibrio aestuarianus strain 01/32 onlethality and cellular immune responses of the oyster Crassostrea gigas. Dev. Comp.Immunol. 30, 367-379.

Laemmli, U.K., 1970. Cleavage of Structural Proteins during the Assembly of the Head ofBacteriophage T4. Publ. Online 15 August 1970, 680-685.

Lane, E., Birkbeck, T.H., 1999. Toxicity of bacteria towards haemocytes of Mytilus edulis. Aquat. Living Resour. 12, 343-350.

Lane, E., Birkbeck, T.H., 2000. Species specificity of some bacterial pathogens of bivalve molluscs is correlated with their interaction with bivalve haemocytes. J. Fish Dis. 23, 275-279.

Larsen, K.S., Auld, D.S., 1991. Characterization of an inhibitory metal binding site incarboxypeptidase A. Biochemistry (Mosc.) 30, 2613-2618. 
Lee, J.-H., Ahn, S.-H., Lee, E.-M., Kim, Y.-O., Lee, S.-J., Kong, I.-S., 2003. Characterization of the enzyme activity of an extracellular metalloprotease (VMC) from Vibrio mimicus and its Cterminal deletions. FEMS Microbiol. Lett. 223, 293-300.

Mateo, D.R., Siah, A., Araya, M.T., Berthe, F.C.J., Johnson, G.R., Greenwood, S.J., 2009. Differential in vivo response of soft-shell clam hemocytes against two strains of Vibriosplendidus: Changes in cell structure, numbers and adherence. J. Invertebr. Pathol.102, 50-56.

Matozzo, V., Rova, G., Marin, M.G., 2007. Haemocytes of the cockle Cerastoderma glaucum: Morphological characterisation and involvement in immune responses. Fish Shellfish Immunol. 23, 732-746.

May, R.C., Machesky, L.M., 2001. Phagocytosis and the actin cytoskeleton. J. Cell Sci. 114, 1061-1077.

McGwire, B.S., Chang, K.-P., 1996. Posttranslational Regulation of a Leishmania HEXXH Metalloprotease (gp63).J. Biol. Chem. 271, 7903-7909.J. Biol. Chem. 271, 7903- 7909

Miyoshi, S., Shinoda, S., 2000. Microbial metalloproteases and pathogenesis. Microbes Infect. 2, 91-98.

Miyoshi, S., Sonoda, Y., Wakiyama, H., Rahman, M.M., Tomochika, K., Shinoda, S., Yamamoto, S., Tobe, K., 2002. An exocellular thermolysin-like metalloprotease produced by Vibrio fluvialis: purification, characterization, and gene cloning. Microb. Pathog. 33, 127-134.

Mizuta, S., Miyagi, T., Yoshinaka, R., 2005. Characterization of the quantitatively major collagen in the mantle of oyster Crassostrea gigas. Fish. Sci. 71, 229-235.

Moore, C.A., Beckmann, N., Patricia Morse, M., 1992. Cytoskeletal structure of diseased and normal hemocytes of Mya arenaria. J. Invertebr. Pathol. 60, 141-147.

Ochoa-Campuzano, C., Real, M.D., Martínez-Ramírez, A.C., Bravo, A., Rausell, C., 2007. An ADAM metalloprotease is a Cry3Aa Bacillus thuringiensis toxin receptor. Biochem. Biophys. Res. Commun. 362, 437-442.

Paillard, C., Allam, B., Oubella, R., 2004. Effect of temperature on defense parameters in manila clam Ruditapes philippinarum challenged with Vibrio tapetis. Dis. Aquat. Organ. 59, 249-262.

Prado-Alvarez, M., Romero, A., Balseiro, P., Dios, S., Novoa, B., Figueras, A., 2012. Morphological characterization and functional immune response of the carpet shell clam (Ruditapes decussatus) haemocytes after bacterial stimulation. Fish Shellfish Immunol. 32, 6978.

Proctor, R.A., Textor, J.A., Vanin, J.M., Mosher, D.F., 1985. Role of Fibronectin in Human Monocyte and Macrophage Bactericidal Activity. Infect. Immun. 47, 629-637. Saitou, N., Nei, M., 1987. The neighbor-joining method: a new method for reconstructing phylogenetic trees. Mol. Biol. Evol. 4, 406-425

Shinoda, S., Miyoshi, S.-I., 2011. Proteases Produced by Vibrios. Biocontrol Sci. 16, 1-11. Shinoda, S., Miyoshi, S.-I., Wakae, H., Rahman, M., Tomochika, K.-I., 1996. Bacterial Proteases as Pathogenic Factors, with Special Emphasis on Vibrio Proteases. Toxin Rev. 15, 327-339.

Tamura, K., Stecher, G., Peterson, D., Filipski, A., Kumar, S., 2013. MEGA6: Molecular Evolutionary Genetics Analysis version 6.0. Mol. Biol. Evol. mst197.

Teo, J.W.., Zhang, L.-H., Poh, C.L., 2003. Cloning and characterization of a metalloprotease from Vibrio harveyi strain AP6. Gene 303, 147-156.

Travers, M.-A., Mersni Achour, R., Haffner, P., Tourbiez, D., Cassone, A.-L., Morga, B., Doghri, I., Garcia, C.G., Renault, T., Fruitier-Arnaudin, I., Saulnier, D., 2014. First description of French V. tubiashii strains pathogenic to mollusk: I. Characterization of isolates and detection during mortality events. J. Invertebr. Pathol. In press

Travis, J., Potempa, J., Maeda, H., 1995. Are bacterial proteinases pathogenic factors? Trends Microbiol. 3, 405-407.

Tubiash, H.S., Chanley, P.E., Leifson, E., 1965. Bacillary Necrosis, a Disease of Larval and Juvenile Bivalve Mollusks I. Etiology and Epizootiology. J. Bacteriol. 90, 1036-1044.

Tubiash, H.S., Colwell, R.R., Sakazaki, R., 1970. Marine Vibrios Associated with Bacillary Necrosis, a Disease of Larval and Juvenile Bivalve Mollusks. J. Bacteriol. 103, 271-272. 
Figure legends

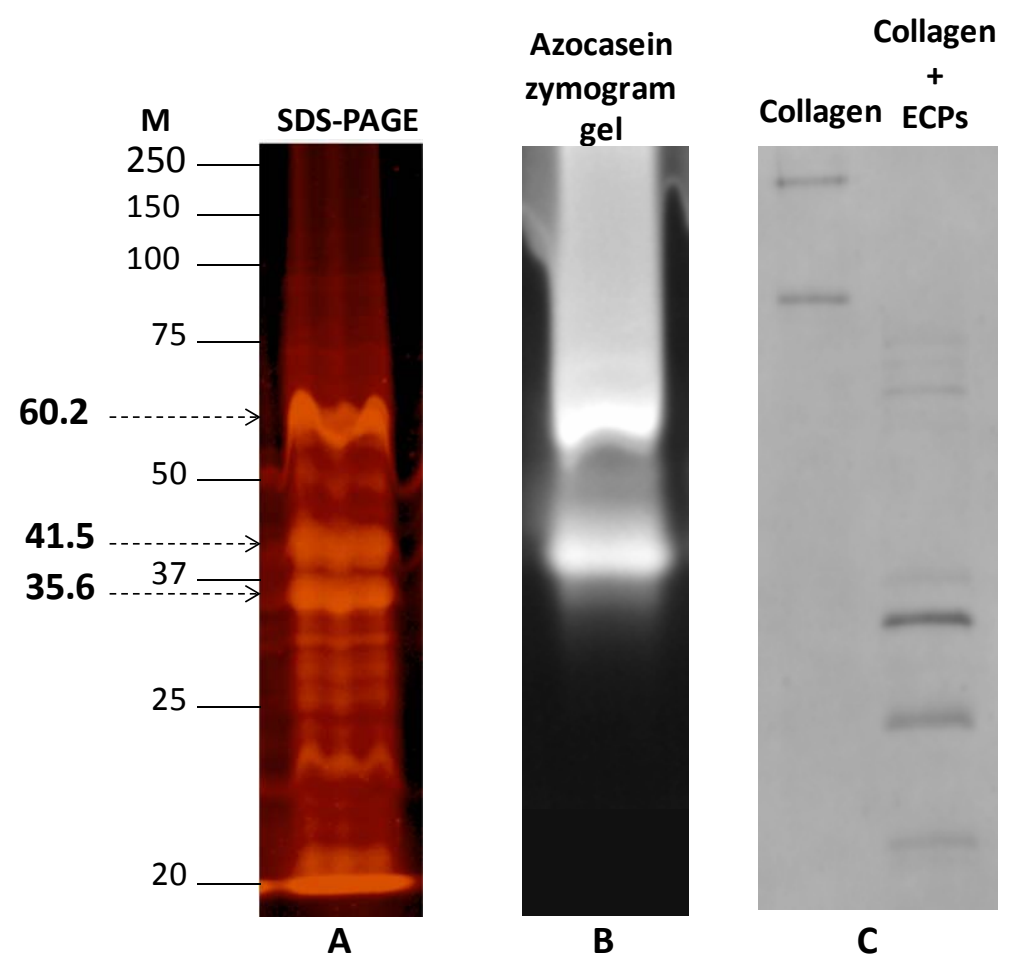

Figure 1: (A) SDS-PAGE and (B) azocasein-gel zymography analyses of the ECPs of $V$. tubiashii 07/118 T2 SDS-PAGE (20 $\mu \mathrm{g}$ of protein/well) was carried out on a $10 \%$ polyacrylamide gel. The gel was stained with Sypro Ruby. A zymography gel was carried out in 10\% SDS-PAGE co-polymerized with $5 \mathrm{mg} / \mathrm{ml}$ of azocasein for the detection of protease activity (20 $\mathrm{\mu g}$ of proteins/well); the gel was stained with Coomassie brilliant blue. (C) Digestion profiles of ECPs $(5 \mu \mathrm{g})$ incubated with oyster collagen $(20 \mu \mathrm{g})$. The gel was visualized by Coomassie blue. M: Molecular weight markers. Arrows showed the molecular weight of the most detected proteins. 

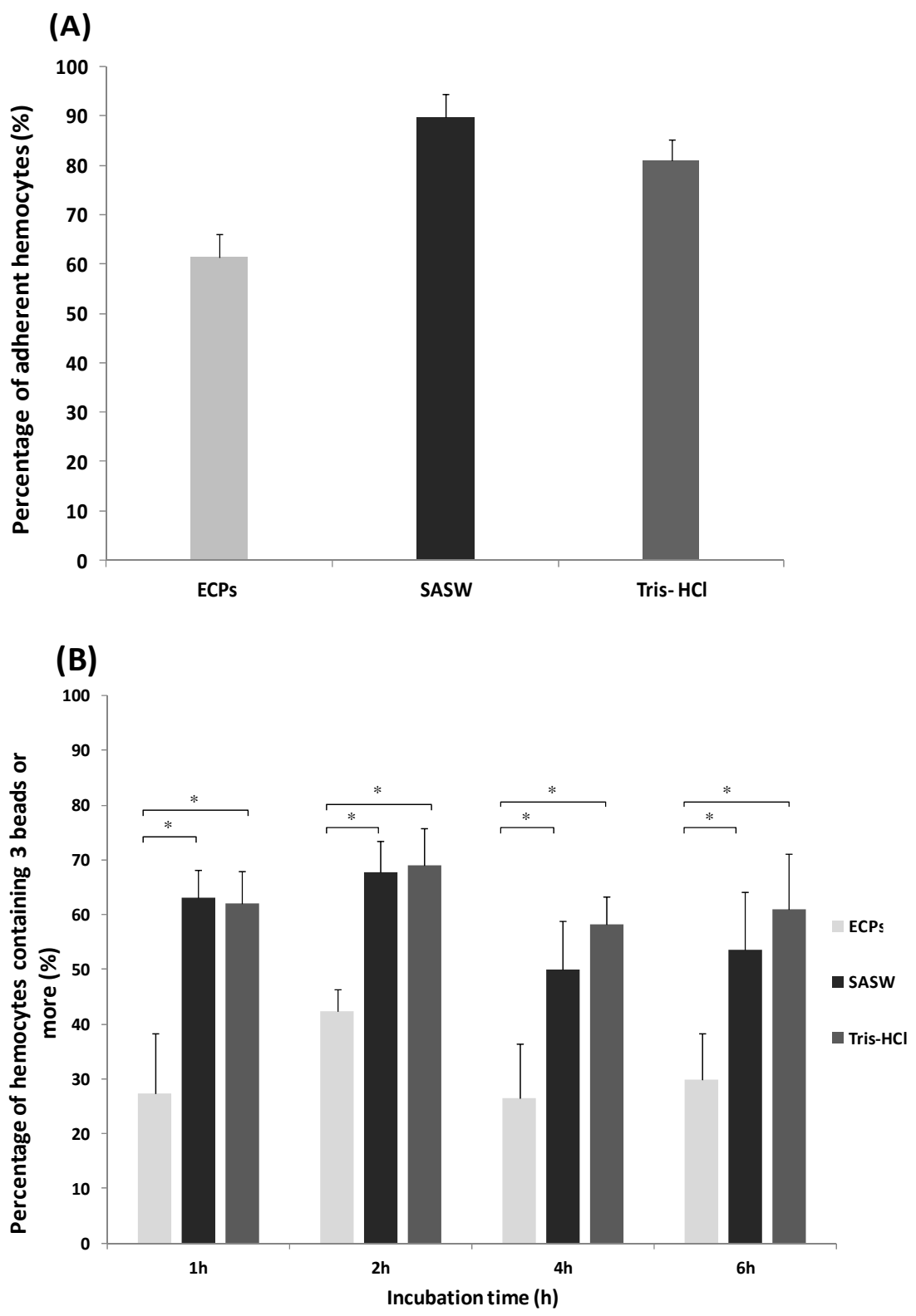

Figure 2: Immune responses of $C$. gigas hemocytes exposed to $V$. tubiashii 07/118 T2 ECPs $(6 \mu \mathrm{g} / \mathrm{ml})$. (A) Effect of ECPs on the capacity of hemocytes to adhere to plastic after a 3 hour incubation. (B) Effect of incubation time on the phagocytic activity of hemocytes (percentage of hemocytes containing more than 3 beads) following contact with $6 \mu \mathrm{g}$ of protein $/ \mathrm{ml}$ of ECPs. An asterisk indicates a significant effect of ECPs (Student's t, $\mathrm{p}<0.05)(\mathrm{N}=3$ biological replicates). 

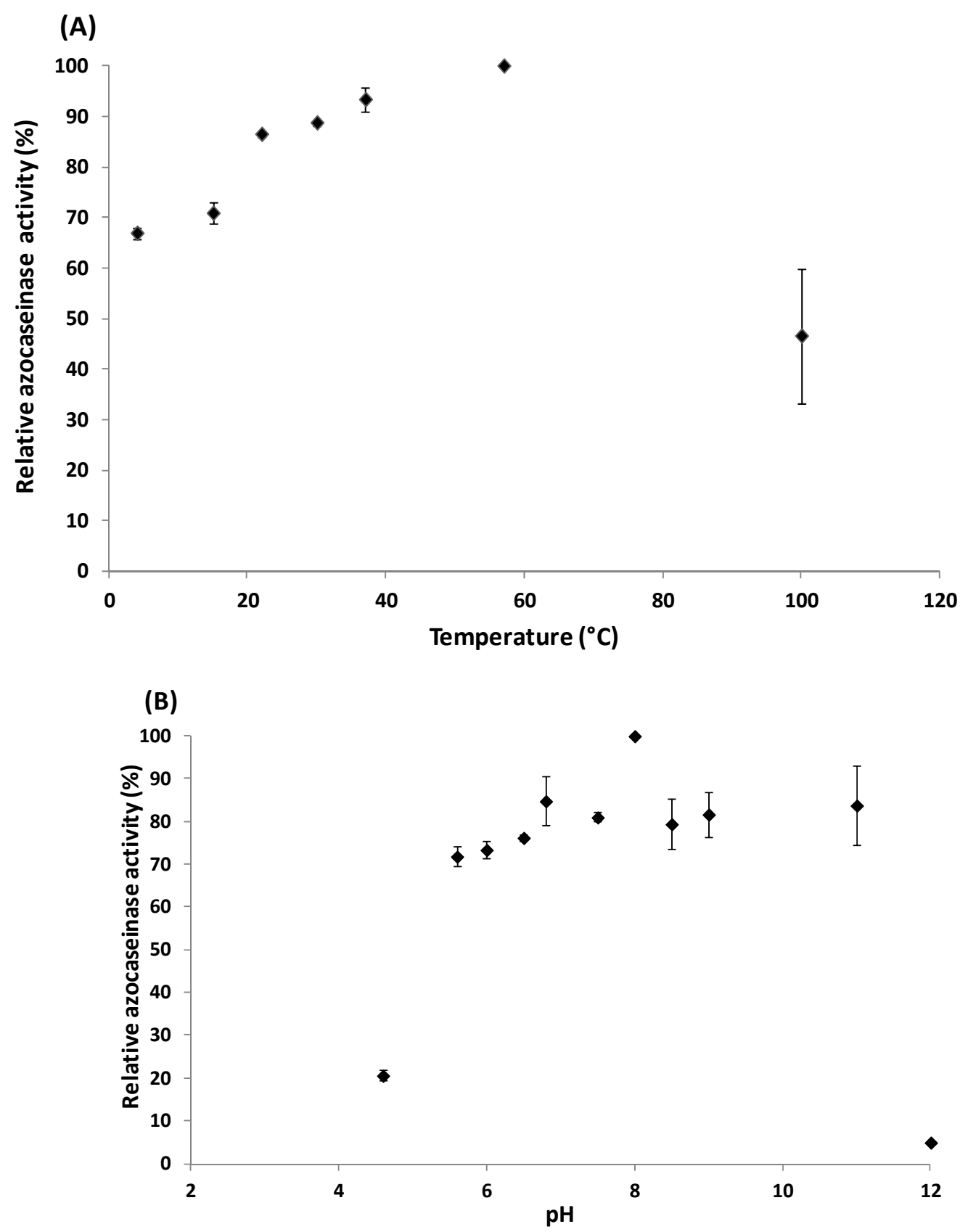

Figure 3: (A) Effect of temperature $\left({ }^{\circ} \mathrm{C}\right)$ and (B) $\mathrm{pH}$ on the azocaseinase activity of the ECPs of $V$. tubiashii $07 / 118 \mathrm{~T} 2(\mathrm{n}=2)$. For optimum temperature, protease activity was assayed at 4 , $15,22,30,37,57$ and $100^{\circ} \mathrm{C}$ and azocasein was used as a substrate. For optimum $\mathrm{pH}$, the protease activity was tested in a $\mathrm{pH}$ range between 4.6 and 11 and protease activity was determined using an azocasein assay. The activity was calculated relative to the reaction at which the maximal activity was obtained (pH 8 and $57^{\circ} \mathrm{C}$ ), which was taken as $100 \%$. 


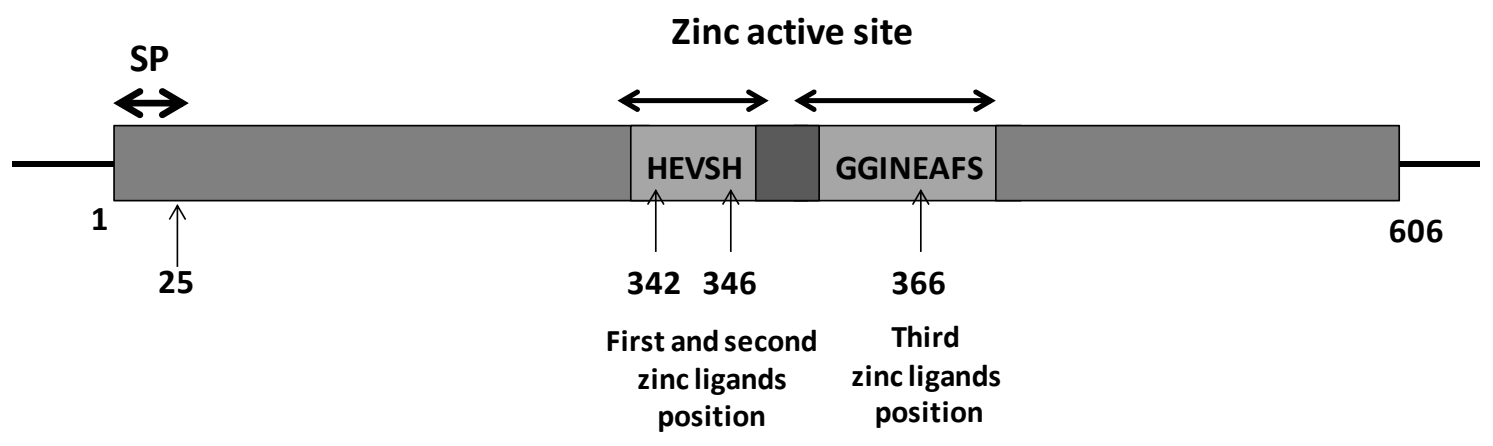

Figure 4: The amino acid sequence of a thermolysin-like metalloprotease (606 aa) from $V$. tubiashii 07/118 T2. The consensus zinc-binding motif is highlighted in light gray. SP: signal peptide. 


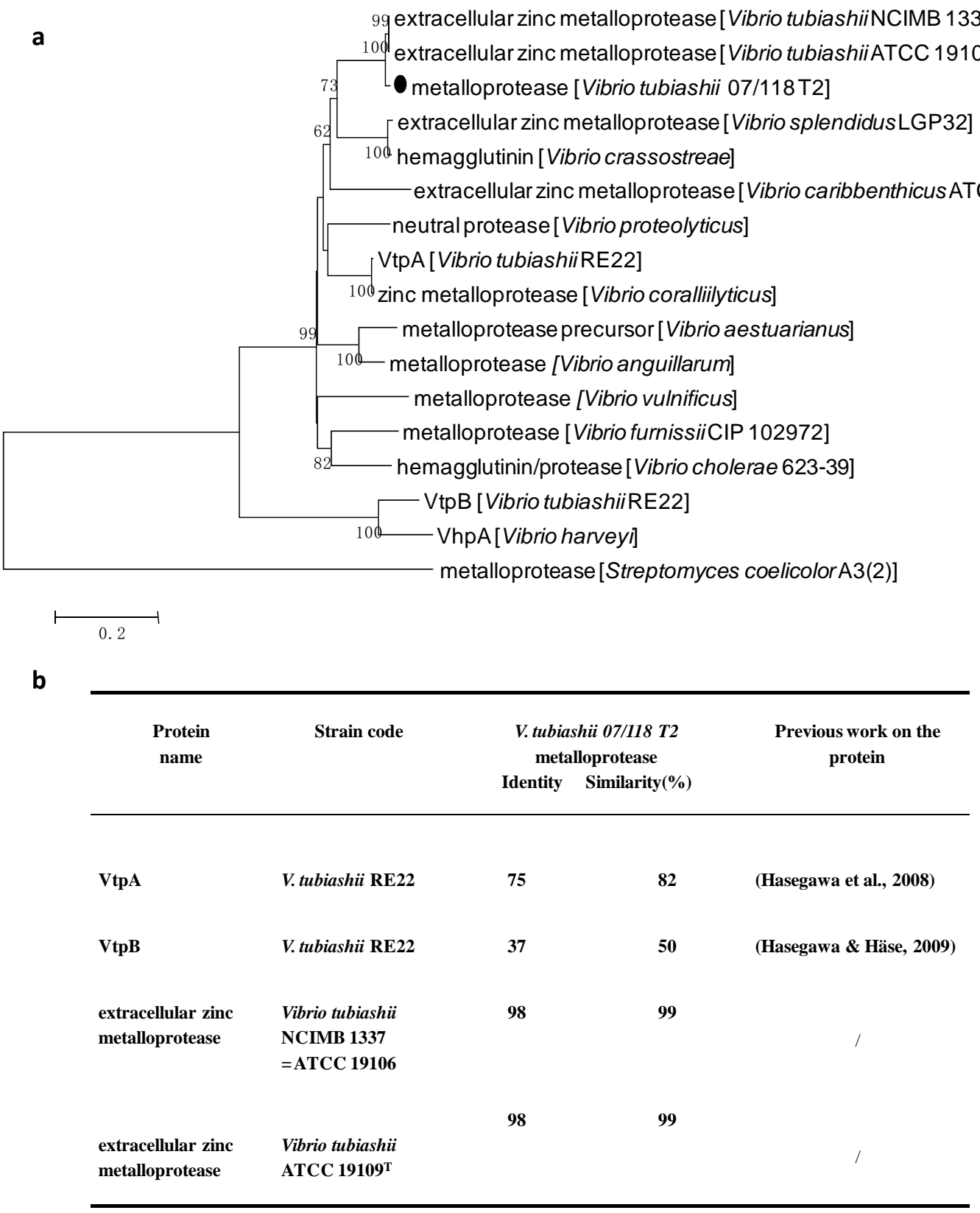

Figure 5: (a) Neighbor-joining phylogenetic tree showing the phylogenetic position of French $V$. tubiashii metalloprotease amino acid sequence $(\bullet)$ compared to other Vibrio metalloprotease amino acid sequences. Phylogenetic analyses were conducted in MEGA 6. The optimal tree with the sum of branch length $=3.17949162$ is shown. The percentage of replicate trees in which the associated taxa clustered together in the bootstrap test (1000 replicates) is shown next to the branches. Nodes without a number are of low significance ( $<50 \%$ ). (b) The percentage identity and similarity of $V$. tubiashii LMG27884 metalloprotease compared to other V. tubiashii metalloproteases (RE 22, ATCC 19106 and ATCC 19109T). /: no published study 
Table 1: Effect of inhibitors and various metal ions on the proteolytic activity of extracellular products from V. tubiashii 07/118 T2 using azocasein (A) and ADAM substrate (B) as substrates.

\begin{tabular}{|c|c|c|c|}
\hline & $\begin{array}{c}\text { Final concentration } \\
\text { mM }\end{array}$ & $\begin{array}{c}\text { (A) } \\
\text { Azocasein } \\
\text { residual activity } \\
(\%)^{\mathrm{a}}\end{array}$ & $\begin{array}{l}\text { (B) } \\
\text { ADAM substrate } \\
\text { residual activity } \\
(\%)^{\mathbf{b}}\end{array}$ \\
\hline $\begin{array}{l}\text { Reagent } \\
\text { None }\end{array}$ & & 100 & 100 \\
\hline $\begin{array}{l}\text { Inhibitors } \\
1,10 \text {-phenanthroline }\end{array}$ & $\begin{array}{c}0.5 \\
5 \\
10\end{array}$ & $\begin{array}{l}18.1 \pm 0.9 \\
19.2 \pm 0.1 \\
25.8 \pm 5.7\end{array}$ & $\begin{array}{l}24.2 \pm 0.6 \\
\text { n.d. } \\
\text { n.d. }\end{array}$ \\
\hline EDTA & $\begin{array}{c}0.5 \\
5 \\
10\end{array}$ & $\begin{array}{c}109.1 \pm 1.4 \\
84.4 \pm 3.5 \\
72.9 \pm 1.6\end{array}$ & $\begin{array}{l}78.1 \pm 1.7 \\
\text { n.d. } \\
\text { n.d. }\end{array}$ \\
\hline PMSF & $\begin{array}{c}0.5 \\
5 \\
10\end{array}$ & $\begin{array}{c}103.8 \pm 0.7 \\
98.2 \pm 2.0 \\
97.1 \pm 0.6\end{array}$ & $\begin{array}{l}53.8 \pm 5.3 \\
\text { n.d. } \\
\text { n.d. }\end{array}$ \\
\hline $\begin{array}{l}\text { Metal ions } \\
\mathrm{ZnCl}_{2}\end{array}$ & 0.2 & $53.7 \pm 1.9$ & $24.8 \pm 0.2$ \\
\hline $\mathrm{CaCl}_{2}$ & 0.2 & $84.1 \pm 3.7$ & $92.5 \pm 2.6$ \\
\hline $\mathrm{MgSO}_{4}$ & 0.2 & $84.1 \pm 0.9$ & $103.0 \pm 0.9$ \\
\hline
\end{tabular}

a The azocaseinase activity of ECPs without the addition of metal ions or inhibitors was taken to be $100 \%$. The effect of metal ions and inhibitors was based on an average of two independent experiments.

${ }^{\mathrm{b}}$ The metalloprotease activity of ECPs without the addition of metal ions or inhibitors was taken to be $100 \%$. The effect of metal ions and inhibitors was based on an average of two independent experiments.

PMSF: Phenylmethanesulfonyl fluoride

EDTA: Ethylendiamine tetraacetic acid

n.d. not done 
Table 2: Mass spectrometry identification of protein contained in $V$. tubiashii 07/118 T2 ECPs. $2 \mu \mathrm{g}$ of crude ECPs were sequenced using LCLTQ Orbitrap Velos mass spectrometry. Score and coverage were those given by the PEAKS software. The MS/MS data obtained were processed and submitted for database search which none (no enzyme) and semiTrypsin were specified for enzyme parameter. MS-MS data were searched against NCBInr database and V. tubiashii ATCC 19109 genome (NCBI).

\begin{tabular}{|c|c|c|c|c|c|c|c|}
\hline Identification & Accession no. & $\begin{array}{l}\text { Cellular component/ } \\
\text { molecular function }\end{array}$ & Sequenced peptides & $\begin{array}{c}\text { Coverage } \\
(\%)\end{array}$ & Score & $\begin{array}{l}\text { MW } \\
\text { (kDa) }\end{array}$ & pI \\
\hline \multicolumn{8}{|l|}{ None (no enzyme) } \\
\hline Extracellular zinc metalloprotease & 343500312 & $\begin{array}{l}\text { Extracellular/ catalytic } \\
\text { activity; metal ion } \\
\text { binding }\end{array}$ & $\begin{array}{l}\text { AEATGTGPGGNLKTNR } \\
\text { AEATGTGPGGNLKTNRY } \\
\text { AEATGTGPGGNLKTNRYD } \\
\text { LVYQNMSGGINEA } \\
\text { LVDINVSAHEVSHG } \\
\text { YSVDDVKAAFTT } \\
\text { IVGADIFKSEGGLRY } \\
+ \text { other peptides }\end{array}$ & 32.62 & 3668.01 & 66.1 & 5.45 \\
\hline N-acetylglucosamine-binding protein A & 343503266 & Extracellular/ND & $\begin{array}{l}\text { VEDQTPPPGD } \\
\text { SVEGPDGFPE } \\
\text { DWNPNQPL }\end{array}$ & 5.77 & 527.87 & 53.1 & 4.69 \\
\hline \multicolumn{8}{|l|}{ SemiTry } \\
\hline Extracellular zinc metalloprotease & 343500312 & $\begin{array}{l}\text { Extracellular/ catalytic } \\
\text { activity; metal ion } \\
\text { binding }\end{array}$ & $\begin{array}{l}\text { AEATGTGPGGNLKTNR } \\
\text { AAADMGYSVDDVKAA } \\
\text { FDQPSKDGR } \\
\text { YSVDDVK } \\
\text { AEATGTGPGGNLK } \\
\text { IVGADIFKSEGGLR }\end{array}$ & 8.9 & 385.48 & 66.1 & 5.45 \\
\hline
\end{tabular}


Supplementary table

Table S1: Genbank accession numbers Vibrio metalloprotease (NCBI)

\begin{tabular}{ll}
\hline Strain & Protein accession \\
& Number \\
\hline Vibrio aestuarianus & AAU04777 \\
Vibrio anguillarum & AAM15681 \\
Vibrio caribbenthicus ATCC BAA-2122 & EFP95808 \\
Vibrio cholerae $623-39$ & ZP 01980763 \\
Vibrio coralliilyticus & AFK08683 \\
Vibrio crassostreae & WP 017063639 \\
Vibrio furnissii CIP 102972 & EEX39831 \\
Vibrio harveyi & AAT68711 \\
Vibrio proteolyticus & AAA27548 \\
Vibrio splendidus LGP32 & YP_002416881 \\
Vibrio tubiashii $[$ NCIMB 1337= ATCC 19106] & EIF02000 \\
Vibrio tubiashii $[$ ATCC 19109 $]$ & EGU55378 \\
Vibrio tubiashii $07 / 118$ T2 & AHG50771 \\
Vibrio tubiashii RE22 & ACD87449 \\
Vibrio tubiashii RE22 & ACS26168. \\
Vibrio vulnificus & AAC45343 \\
Streptomyces coelicolor A3(2) & NP 626768.1 \\
\hline
\end{tabular}

